\title{
Evaluation of High Yielding Strains of Oyster Mushroom (Pleurotus spp.)
}

\author{
Sharad Shroff* \\ RMD College of Agriculture and Research Station Ajrima, Ambikapur, \\ Indira Gandhi Krishi Vishwavidalaya Raipur, Chhattisgarh, India \\ *Corresponding author
}

\begin{abstract}
A B S T R A C T
Five strains of oyster mushroom were tested for various parameters such as spawn run days, pin head initiation days, days taken for first harvest, fruit body/bag, and average weight of fruit body, yield and biological efficiency. Results indicate that highest biological efficiency was recorded in strain R-13-13-05 (96.6\%) followed by strain R-1313-07 (75.3 \%), R-13-13-03 (74.8\%) and R-51 (66.4 \%), respectively, and Lowest BR was observed in strain R-13-13-04 (58.4\%) among all the tested strains. Days required for spawn was minimum in strain R-13-13-05 (only 17 days) followed by R-13-13-04 (only 17.67 days), strains R-13-13-07, R-51 (only 18.67 days) and strain R-13-13-03 (only 19.83 days), respectively. Maximum required days, for spawn run, were recorded in strain R-1313-3 (total 20.33 days). Pin head initiation was first reported in strain R-13-13-5 (within 20.67 days) followed by strain R-51 (within 23.50 days), strains R-13-13-04 (within 24.17 days) and strain R-13-13-03 (within 24.67 days), respectively. Maximum days, required for pin head initiation, were in strain R-13-13-07 (within 25.0 days). First harvesting was done in strain R-13-13-05 (after 25.33 days of spawning) followed by strains R-13-13-03, R-13-13-07, R-51 and R-13-13-04 (after 27.33, 27.33, 27.50, 29.50 days of spawning, respectively). Among all the strains, tested in the experiment, strain R-13-13-07 recorded highest fruit body weight (per fruit body $26.55 \mathrm{~g}$ ) followed by R-13-13-04 $(25.50 \mathrm{~g})$, strains R-13-13-05, (19.86g ) and R-51 (17.33 g ), respectively. Lowest weight, per fruit body, was recorded in strain R-13-13-03 (14.52 g). Strain R-13-13-03 yielded maximum fruit body (61.33 fruits/bag) followed by R-51 (60.33 fruit body/bag), strain R-13-13-04 (51.50 fruit body/ bag) and R-13-13-05 (51.33 fruit body/bag), respectively. Minimum fruit body was yielded in strain R-13-13-07 (31.0 fruit body/bag).
\end{abstract}

\section{Introduction}

Mushroom cultivation is a profitable agribusiness world-wide. There are more than 5000 mushroom varieties could be employed for foods and medicines. In the fungal classification system proposed by Ainsworth and followed by J. Webster (Sharma, 1989), almost edible mushrooms are members of the subdivision Basidiomycotina and Ascomycotina (Dung, 2007). Oyster mushrooms could prevent and reduce several serious diseases, including high blood pressure and cholesterols (Agrawal et al., 
2010), and breast cancer, prostate cancer (Jedinak and Sliva, 2008).

With objectives of identification of high yielding varieties or strains the five strains of oyster mushroom collected from the Department of Plant Pathology, College of Agriculture Raipur, IGKV Raipur Chhattisgarh and experiments was conducted in RMD College of Agriculture and Research station, Ajrima, Ambikapur for various yield parameters for such as spawn run days, pin head initiation days, days taken for first harvest, fruit body per bag, average weight of fruit body and yield.

\section{Materials and Methods}

\section{Collection of strains}

Five strains (R-13-13-03, R-13-13-04, R-1313-05, R-13-13-07 and R-51) of oyster mushroom (Pleurotus spp.) were collected from College of Agriculture, Department of Plant Pathology IGKV Raipur (C.G).

\section{Site of experiment}

Experiment was conducted in mushroom hut of Division of Plant Pathology at RMD College of Agriculture and Research station Ajrima, Ambikapur (C.G) during month of January to march 2014.

\section{Experimental details}

Experiment was carried out during Rabi season with date of spawning is last week of January 2014 in mushroom hut by using Complete Randomized Block Design (CRD).

Five treatment in three replication and each replication consist of two bags wheat straw is used as substrate ( $2 \mathrm{~kg}$ wet wt. of wheat straw) by using $3 \%$ of spawn rate (wet wt. of substrate) in poly bag of size (12" x 18 ").

\section{Data collection and Statistical analysis}

The experiment was laid out in Completely Randomized Design (CRD) with five treatments with three replications. The data were recorded on spawn run days, pin head initiation days, days taken for first harvest, number of fruit body/bag, and average weight of fruit body, mean yield and biological efficiency. The data were analyzed by statistical procedure given by Gomez, K.A. and Gomez, A.A. 1984.

\section{Results and Discussion}

\section{Spawn run (Days)}

Days required for spawn was minimum in strain R-13-13-05 (only 17 days) followed by R-13-13-04 (only 17.67 days), strains R-1313-07, R-51 (only 18.67 days) and strain R13-13-03 (only 19.83 days), respectively. Maximum required days, for spawn run, were recorded in strain R-13-13-3 (total 20.33 days). Similar result also found by Shah et al., (2004). Ahmed (1998) stated that P. ostreatus completed spawn running in 17-20 days on different substrates $\mathrm{He}$ reported that the spawn running took 16-25 days after inoculation. Similar results also reported by Tan (1981)

\section{Pin head initiation (Days)}

Pin head initiation was first reported in strain R-13-13-5 (within 20.67 days) followed by strain R-51 (within 23.50 days), strains R-1313-04 (within 24.17 days) and strain R-13-1303 (within 24.67 days), respectively. Maximum days, required for pin head initiation, were in strain R-13-13-07 (within 25.0 days). Similar result also found by Shah et al., 2004 found that the spawn heads appeared 6 days after the spawn running. Ahmed (1998) stated that $P$. ostreatus completed spawn running in 17-20 days on 
different substrates and time for pinhead formation was noted at 23-27days.

\section{Days taken for first harvest (Days)}

First harvesting was done in strain R-13-1305 (after 25.33 days of spawning) followed by strains R-13-13-03, R-13-13-07, R-51 and R13-13-04 (after 27.33, 27.33, 27.50, 29.50 days of spawning, respectively). similar result also found by Bugarski et al., (1994) who found that the first fruiting occurred on different days depending on types of strains.

\section{Fruit body/ bag}

Strain R-13-13-03 yielded maximum fruit body (61.33 fruits/bag) followed by $\mathrm{R}-51$ (60.33 fruit body/bag), strain R-13-13-04 (51.50 fruit body/ bag) and R-13-13-05 (51.33 fruit body/bag), respectively. Minimum fruit body was yielded in strain R-13-13-07 (31.0 fruit body/bag). Higher number of effective fruiting body might happen due to the presence of glucose, fructose and trehalose in the substrate, reported by Kitamoto et al., (1995) (Fig. 1a and Table 1).

Table.1 Evaluation of high yielding varieties/strains of oyster mushroom (Pleurotus spp.)

Date of sowing: $30-01-2014$

\begin{tabular}{|c|c|l|l|l|l|l|l|l|}
\hline S.N & Treatments & $\begin{array}{l}\text { Spawn } \\
\text { run(days) }\end{array}$ & $\begin{array}{l}\text { Pin head } \\
\text { initiation } \\
\text { (days) }\end{array}$ & $\begin{array}{l}\text { Days } \\
\text { taken for } \\
\text { first } \\
\text { harvest }\end{array}$ & $\begin{array}{l}\text { Fruit } \\
\text { body/ } \\
\text { bag }\end{array}$ & $\begin{array}{l}\text { Average } \\
\text { weight of } \\
\text { fruit body } \\
\text { (g) }\end{array}$ & $\begin{array}{l}\text { Mean } \\
\text { yield } \\
\text { (kg) }\end{array}$ & BE \\
$\mathbf{( \% )}$
\end{tabular}

Fig.1a

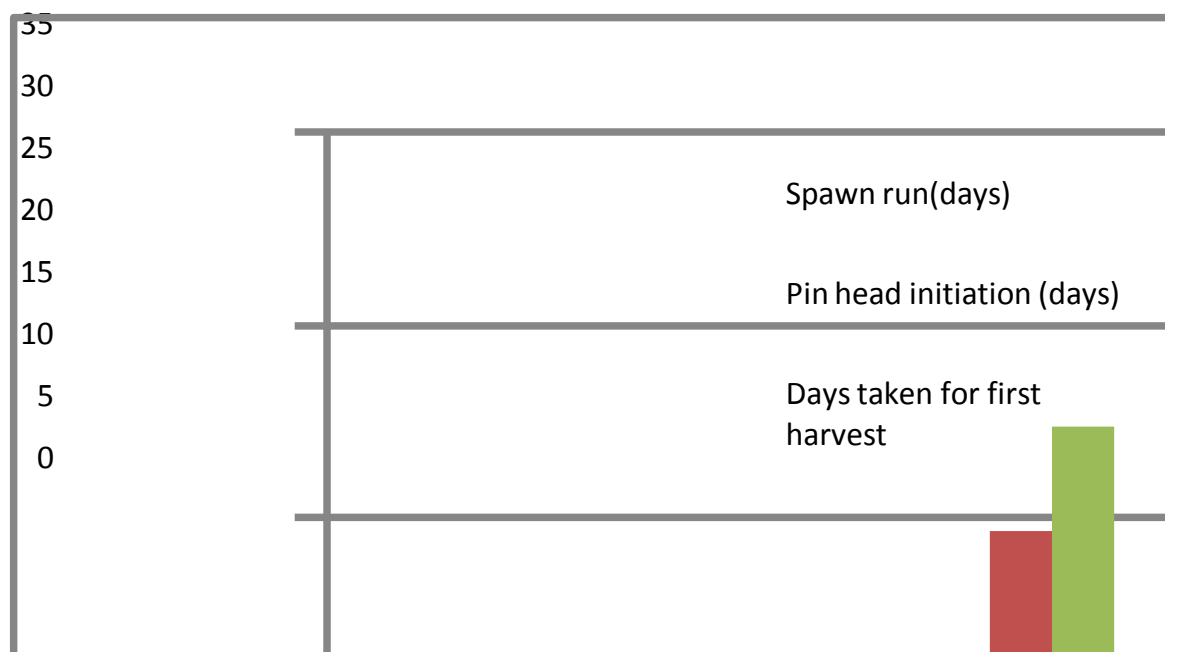


Fig.1b

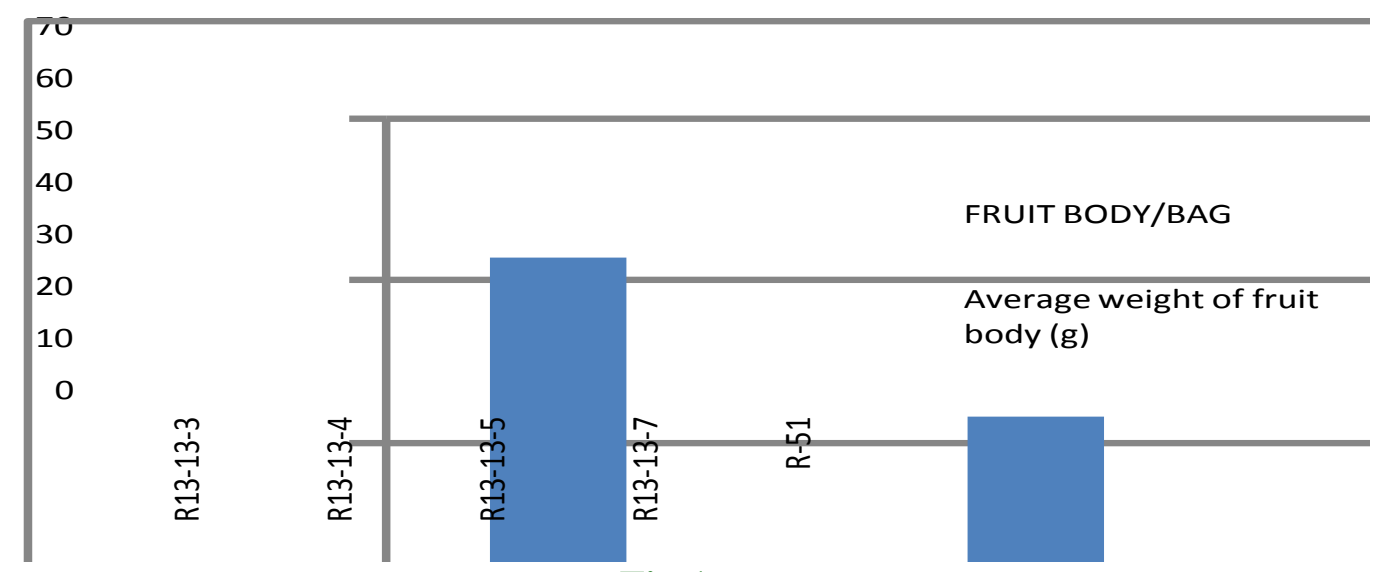

Fig.1c

Mean yield (kg)

0.6

0.5

0.4

0.3

0.2

0.1

Mean yield $(\mathrm{kg})$

0

\begin{tabular}{|c|c|c|c|}
\hline $\begin{array}{ll}\ddot{m} & \dot{r} \\
\ddot{n} & \stackrel{\ddot{m}}{\ddot{n}}\end{array}$ & 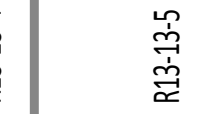 & $\begin{array}{l}\stackrel{\text { m}}{\dddot{g}} \\
\dot{\ddot{q}}\end{array}$ & 官 \\
\hline
\end{tabular}

Fig.1d

\section{Biological effieciency \%}

120

100

80

60

40

20

0
Biological effieciency \%

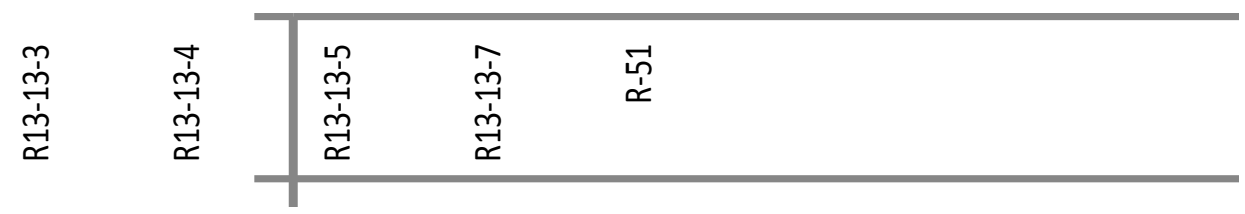


Phytoplates

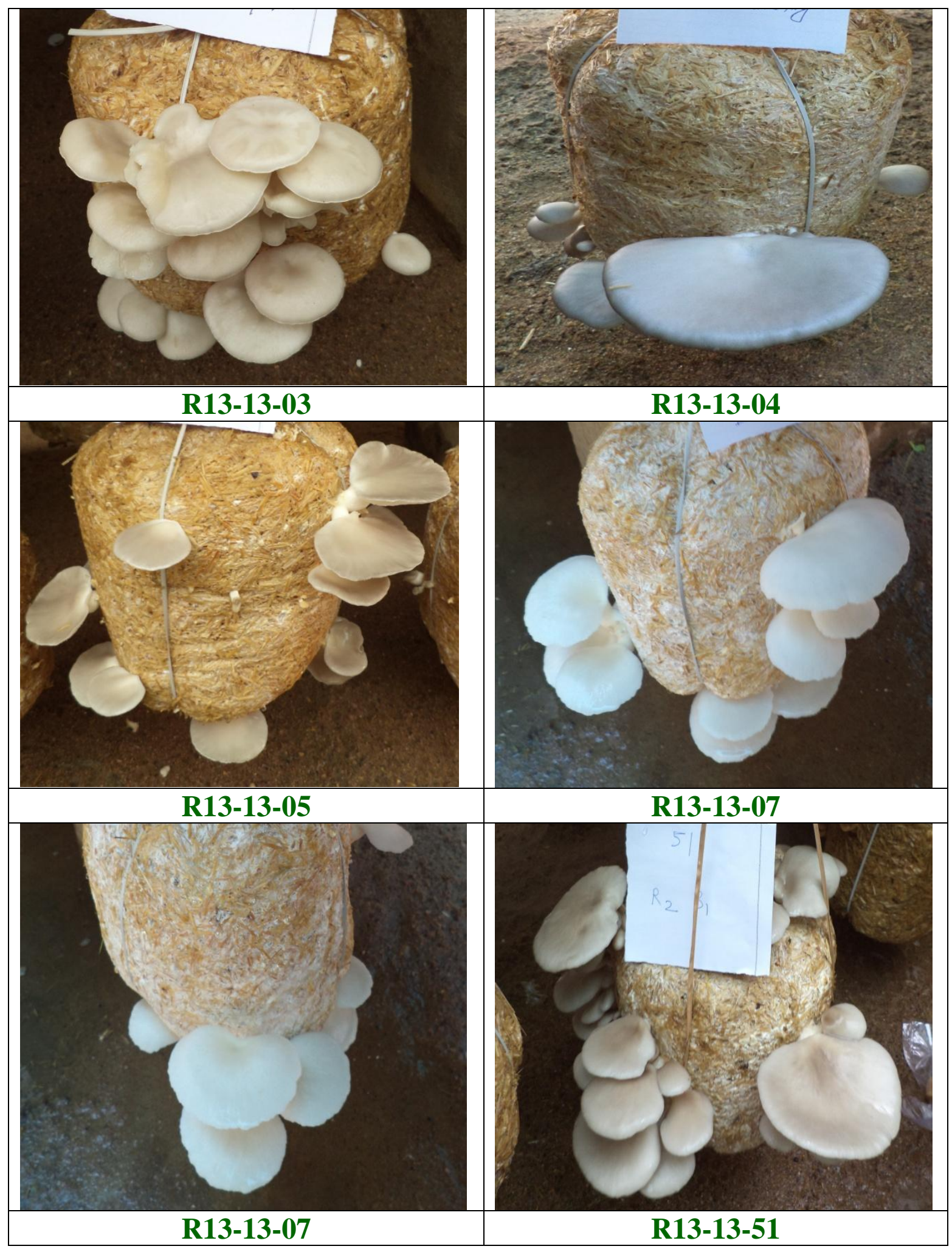


Poppe (1973) found that Indole Acetic Acid (IAA) increased the number of fruiting body of mushroom.

\section{Average weight of fruit body (G)}

Among all the strains, tested in the experiment, strain R-13-13-07 recorded highest fruit body weight (per fruit body $26.55 \mathrm{~g}$ ) followed by R13-13-04 (25.50 g), strains R-13-13-05, (19.86g) and R-51 (17.33 g), respectively. Lowest weight, per fruit body, was recorded in strain R-13-13-03 (14.52 g).

\section{Biological yield}

Highest biological efficiency was recorded in strain R-13-13-05 (96.6\%) followed by strain R-13-13-07 (75.3 \%), R-13-13-03 (74.8\%) and R-51 (66.4\%), respectively (Fig. 1b and c).

Lowest BR was observed in strain R-13-13-04 $(58.4 \%)$ among all the tested strains. Kausar \& Iqbal (1994) reported that yield varied from 18.6 to $83.5 \%$ on the basis of different nitrogen supplements amended with straw. Kausar \& Zafar (1995) reported that average yield varied from 57.17- 73.39\%.

Jiskani et al., (1999) obtained 24 and 7.6\% fresh and dry yield on the basis of substrate dry weight, in case of using wheat straw. Jiskani (1999) reported that $100 \%$ of substrate dry weight means one $\mathrm{kg}$ of fresh mushroom can be obtained from one kg of dry substrate (before soaking and boiling).

According to Bughio (2001) the maximum fresh (wet) and dry yield percentage on substrate dry weight basis (29.61 to 77.91 and 5.91 to 21.70 ) were obtained from wheat straw using in combination with cotton boll locules, paddy straw, sugarcane and sorghum leaves at 1:1 ratio in case of using sorghum grain spawn @ $30 \mathrm{~g}$ per bag.

\section{Acknowledgements}

I thankful to all my friends, colleague, seniors, and ground workers, who directly or indirectly involved in research work carried out during research program and special thanks to my university and institution for their financial support or funding.

\section{References}

Ahmed, S. 1998. Development of mushroom varieties suitable for rural level in Bangladesh. Report presented in BARC Annual Review Programme: Page 72-73.

Badshah, N., N. Ur-Rehman and M. Wahid. 1992. Yield and quality of mushrooms grown on different substrates. Sarhad J. Agriculture, 8(6): 631-635.

Bano, Z., Nagaraja, N., Rajrathnam, S. and Pathwardhan, M.V. 1979. Cultivation of Pleurotus spp. In a village model hut. Indian Fd. Packer. 33(6): 9-25.

Bugarski, D., Gvozdenovic, D., Takae, A. and Cervenski, J. 1994. Yield and yield components of different strains of oyster mushroom. Savremena poljoprivreda (Yugoslavia). 42 (1): 314-318.

Bughio, I. 2001. Yield performance of oyster mushroom, Pleurotus ostreatus (Jacq. ex. Fr.) Kummer on combination of different straws. M. Sc. Thesis, Deptt. of P. Path. S.A.U. Tandojam. pp. 69.

Chang, S.T. and Miles, P.G. 1988. Edible Mushroom and their cultivation. CRC press, Inc. Boca Raton, Florida U.S.A. 27:83-88.

Dung, N. L. 2007. Techniques of Mushroom cultivation (vol 1) (in Vietnamese). Ha Noi: Agriculture.

Gohl, G. 1993. Tropical Feeds. Published by Food and Agriculture Organization of United Nation. Revised by Andrew speedy computer journal version-4.

Gomez, K.A. and Gomez, A.A. 1984. Statistical procedure for Agricultural research. 2nd edition. John Wiley and Sons, New York. $680 \mathrm{pp}$.

Jiskani, M. M. 1999. A brief outline "The fungi" Cultivation of mushrooms. Izhar Pub. Tandojam. p.94.

Jiskani, M. M., M. A. Pathan and K. H. Wagan. 
1999. Yield performance of oyster mushroom, Pleurotus florida (Strain Pk401) on different substrates. Pak. Jr. Agri., Agril. Engg. Vet. Sci., 15 (2): 2629.

Kausar, T. and S. I. Zafar. 1995. Introduction of tower system for the cultivation of mushrooms (Pleurotus spp.). Pak. J. Sci. Ind. Res., 38 (9-10): 362-364.

Kausar, T. and S. H. Iqbal. 1994. Supplementation of rice straw with various nitrogen sources to improve the yield of P. sajor-caju. Pak. J. Sci. Ind. Res., 37 (1-2): 615-519.

Kausar, T. and S. I. Zafar. 1995. Introduction of tower system for the cultivation of mushrooms (Pleurotus spp.). Pak. J. Sci. Ind. Res., 38 (9-10): 362-364.

Kitamoto, Y., Horkoshi, T., Hosio, N. and Ichikawa, Y. 1995. Nutritional study of fruiting-body formation in Psilocybe panaeoliformis. Trans. Mycol. Soc. (Japan). 16(3): 268.

Mueller, M. and Cantner, E.W. 1990. Mushroom cultivation for feed and food. Entwicklung-und-laendlicher-Raum (Germany, F.R.). 22(2) 15-17.

Poppe, J.A. 1973. The fruit regulating action of light and chemicals in the culture of $P$. spp (Fr.) Medeligen, Vande Paculteit Land bouwweten sheappen. 38(3): 13871397, (cited from Hort. Abst. 44(2): 1974-9737).

Quimio, T.H. 1980. Survey and culture of edible ones, in cultivation of edible mushroom in tropics, UNESCO, Regional workshop, Manila.

Reyes, R.G., Abella, E.A. and Evangelista I.B. (1993). Adaptability of Asian isolates of Pleurotus sajor - caju using the Central Luzon State University Technology.
CLSU Scientific Journal. 14: 29 -36.

Reyes, R.G., Abella, E.A., Eguchi, F. and Higaki, M. (1997). State of the art of mushroom production activities in the province of Nueva Ecija, Philippines. Mushroom Science and Biotechnology. 4: 3-8.

Reyes, R.G., Eguchi, F., Iijima, T. and Higaki, M. (1998). Physiological considerations for the efficient colonization of fukurotake, Volvariella volvacea. Journal of Wood Science. 44: 408-413.

Reyes, R.G., Encarnacion, A.D. and Abella, E.A. (1993). Utilization of selected agroindustrial wastes for mushroom (Pleurotus sajor-caju) production. CLSU Scientific Journal. 14: 9-23.

Shah, Z. A., Ashraf and Ishtiaq, M.C. 2004. Comparative study on cultivation and yield performance of Oyster mushroom (Pleurotus ostreatus) on different substrates (wheat straw, Leaves and Sawdust). Pakistan J. Nutrition. 3(3): 158160.

Sharma, O. P. 1989. Textbook of Fungi. 5th edn. New Delhi: Tata McGraw-Hill.

Tan, K.K. 1981. Cotton waste is fungus (Pleurotus) good substrates for cultivation of Pleurotus ostreatus, the Oyster mushroom. Mushroom Sci. 11: 705-710.

Wang, C.W. 1982. Cellulolytic enzymes of Volvariella volvacea Tropical Mushrooms Biological Nature and cultivation methods (ed.) S.T. Chang and T.H. Quimio, The Chinese University press, Hongkong.

Zhang, R.H., Li, X.J. and Fadel, J.G. 2002. Oyster mushroom cultivation with rice and wheat straw. Bioresour. Technol. 82(3): 277-284.

\section{How to cite this article:}

Sharad Shroff. 2019. Evaluation of High Yielding Strains of Oyster Mushroom (Pleurotus spp.). Int.J.Curr.Microbiol.App.Sci. 8(06): 1054-1060. doi: https://doi.org/10.20546/ijcmas.2019.806.129 